\title{
COMBATING POVERTY AS A MAIN CHALLENGE OF SUSTAINABLE DEVELOPMENT: THE CASE OF BRAZIL'S BOLSA FAMIILIA
}

\section{Introduction}

The United Nations (UN) Conference on Environment and Development in Rio de Janeiro in 1992 marked a sustainable development milestone. However, after decades of implementing different approaches to poverty reduction in the realm of sustainable development, the solution to extinguish poverty seems to be out of reach. The introduction of 17 Sustainable Development Goals (SDGs) in 2015 with lessons learned from the Millennium Development Goals (MDGs) that need to be achieved until 2030 mark another milestone in the path towards a coherent sustainable policy at the global level. Although an abundance of definitions of the sustainable development concept exists, the UN still uses the definition by the Brundtland Commission from 1987, which states: "Sustainable development is development that meets the needs of the present without compromising the ability of future generations to meet their own needs, [...] in particular the essential needs of the world's poor, to which overriding priority should be given"'. The UN aims at eradicating poverty in all its dimensions and forms, which is, according to the UN, the "greatest global challenge and indispensable requirement for sustainable development". Poverty reduction as a crucial element to combat one of the most degrading conditions a human being can face. Therefore, the first SDG goal marks this effort in ending poverty in all its forms everywhere ${ }^{2}$.

Now the world faces a new challenge: poverty in middle-income countries (MICs). Until the 1990 s, $90 \%$ of the world's poor lived in low-income countries; nowadays

Collegium of Socio-Economics, Warsaw School of Economics.

1 WCED, Our common future. Report of the World Commission on Environment and Development, G.H. Brundtland, (Ed.), Oxford 1987.

2 United Nation's Sustainable Development Knowledge Platform, Poverty eradication, 2015, https:// sustainabledevelopment.un.org/topics/povertyeradication 
$70 \%$ of the poor live in MICs. Populous countries such as Brazil, Nigeria, China and India graduated from the low-income status due to rapid economic growth, however, leaving behind a substantial portion of their population in poverty ${ }^{3}$. Therefore, alternative solutions to sustainable development are needed as former policies seem to have helped developing countries to graduate to MICs, but omitting the aspect of sustainable poverty reduction. Moreover, these emerging countries attempting to move towards an advanced economy status have difficulty in their sustainable development strategies not only with economic factors but also social and environmental ones. Thus, novel approaches to international cooperation are needed, which are designed to tackle common challenges jointly, while ideas are shared, knowledge is exchanged and mutual learning is fostered.

As Ban Ki-moon phrased it in the Secretary-General's message on the UN Day for South-South Cooperation in 2013, he mentioned the Brazilians' conditional cash transfer (CCT) Bolsa Família Programme (BF) as a poverty reduction solution, which meaningfully contributed to fields such as hunger reduction, health, empowerment and education across the globe ${ }^{4}$. Considering the correctness of this assessment, BF could offer concrete solutions to common challenges in sustainable development.

$\mathrm{BF}$, launched in 2003, is the largest conditional cash transfer (CCT) programme worldwide and its success is noted worldwide. Numerous countries and international organisations (IOs) have turned to Brazil for assistance in public policy. In total, 63 countries have sent experts to Brazil in order to investigate BF and already 40 countries have implemented a copy of BF, such as Indonesia, Morocco, South Africa, Turkey and US cities, namely, New York and Memphis 5 . As Brazil's CCT programme, $\mathrm{BF}$ is seen as a model by other nations from the Global South and is being exported to numerous countries, the aim of the essay is to assess if BF is a suitable poverty alleviation policy in the realm of sustainable development for other countries by evaluating BF impacts with the help of SDGs as a reference point. Regarding the scope of the research, economic, social and political considerations will be taken into account.

3 T. Gönner, Beyond Development Aid: Novel International Cooperation Approaches with Emerging Economies, Global Economic Symposium, Berlin 2013, p. 3.

4 United Nations, United Nations Secretary-General Ban Ki-Moon, 2013, http://www.un.org/sg/STATEMENTS/index.asp?nid=7072 (retrieved: 13.10 .2017 ).

5 J. Tepperman, Brazil’s Antipoverty Breakthrough, "Foreign Affairs” 2016, 95(1), p. 44. 


\section{Bolsa Família: Its Design and Implementation}

CCTs as an anti-poverty policy enjoy popularity; although the concept is not new at the global scale as well. The first promising CCT was Progresa in Mexico in 1997. Until 2000, only three countries had implemented CCT programmes: Mexico, Brazil and Bangladesh. Since then, large-scale CCT programmes have been introduced in almost every Latin American country, widely in Asia and to a lesser extent adopted in Africa, mainly supported by $\mathrm{WB}^{6}$. At present, a multitude of CCT programmes exists, which differ in their conditionality, scope or coverage, beneficiaries and length of time. In this light, it is clear that social policies evolve out of a specific national context. Thus, the question arises why BF is so popular among other countries.

CCTs are politically acceptable and not regarded as mere 'hand-outs'. Historically, taxpayers have been critical towards welfare policies as their money goes to the non-working population. But due to the fact $\mathrm{BF}$ is based on the conditions which are explained below, poor families also have to make an effort, otherwise they lose the transfer ${ }^{7}$. At present, the programme covers 13.8 million families that constitute approximately forty-eight million people, representing $100 \%$ of the poor and $25 \%$ of the Brazilian population ${ }^{8}$ and at least two-thirds being extremely poor ${ }^{9}$. The spending on the BF programme consisted in 2013 of $\mathrm{R} \$ 23$ billion (EUR 6.21 billion), hence $0.5 \%$ of the GDP. Although so many families are covered by BF, improving their lives by the additional cash transfer, in regard with the public spending, BF constitutes a rather small expenditure. Another indication of its relatively low cost is that the total social spending amounts to less than $3 \%$ in Brazil ${ }^{10}$.

$\mathrm{BF}$ as a poverty alleviation programme is highly unique in its system. Therefore, the design in respect to targeting, transfer and conditionality will be assessed. First of all, extremely poor ${ }^{11}$ and poor ${ }^{12}$ families are targeted by BF throughout the

6 M. Curry et al., Brazil's Bolsa Familia and the Philippines' "4Ps" CCT Programs: Considering South-South Cooperation for Social Protection, "Asia-Pacific Social Science Review" 2013, 13:1, p. 1.

7 K. Lindert et al., The Nuts and Bolts of Brazil's Bolsa Familia Program: Implementing Conditional Cash Transfers in a Decentralized Context, Social Protection Discussion Paper 709, The World Bank, Washington D.C. 2007, p. 45.

8 The Central Intelligence Agency estimates that the total population of Brazil is approximately 204 million.

9 ILO, Bolsa Familia: An International Example of Social Inclusion. An Interview with Helmut Schwarzer, 2015, http://www.socialsecurityextension.org/gimi/gess/ShowWiki.action?wiki.wikild=3044 (retrieved: 16.11.2017).

10 A.W. Pereira, Bolsa Família and Democracy in Brazil, “Third World Quarterly" 36(9), 2015, pp. 1683.

11 The World Bank defines extreme poverty as living on less than US\$1.90 per day.

12 As moderate poverty the World Bank defines living on less than U\$3.10 a day. 
country based on per capita income. The regular profile of beneficiaries constitutes of people who are working in precarious jobs in the informal sector, who receive an income that is insufficient to satisfy their basic needs and/or whose income is complemented by the benefit. Hence, $\mathrm{BF}$ is vital as a relief of deprivations ${ }^{13}$. The average transfer per beneficiary on a per capita basis represents around $6 \%$ of the Brazilian minimum wage, which, however, only constitutes $19 \%{ }^{14}$ of the poverty line used by the $\mathrm{WB}^{15}$. The actual minimum wage in Brazil is $\mathrm{R} \$ 545$ (EUR $\left.147.15^{16}\right)^{17}$.

Secondly, the transfer considers family composition (whether breastfeeding women, children under 15 and juveniles between 16 and 17) and income, providing basic, variable or youth variable types of benefits as depicted in Table 1. Hence, families are classified and receive transfers in regard to their poverty intensity and number of children. For example, the basic benefit is received by extremely poor families, regardless of having or not having offspring. Additionally, extremely poor families receive a variable or/and a youth variable benefit which is set according to the number of children and youth in the household. The same variable benefit applies to moderately poor families ${ }^{18}$. Hence, families could receive up to three types of benefits with a range of aggregated value between $\mathrm{R} \$ 32.00$ (EUR 8.53) and $\mathrm{R} \$ 306.00$ (EUR 81.59). Therefore, extremely poor families are eligible for the basic benefit of $\mathrm{R} \$ 70$ (EUR 18.66) and variable benefits, often reaching the maximum possible value of R 306 (EUR 81.59). Moderately poor families are not allowed to receive more than $\mathrm{R} \$ 236$ (EUR 62.92) ${ }^{19}$. In the assistance family as a whole is defined; however, according to the law where BF was established, payments are given preferentially to women as the legally-responsible beneficiary in each family. In 2005, 93\% of all beneficiaries were women. The reason for the gendered preference in payments is due to the fact that women invest most likely more income in improving health, education and welfare of their families and specifically children, which is also reflected by international experience ${ }^{20}$.

13 C.L. Kerstenetzky, Redistribution and Development? The Political Economy of the Bolsa Família Program, "Dados" 2013, vol. 10, Rio de Janeiro p. 18.

14 According to the World Bank criteria, the Brazilian government considers as "extremely poor" families whose per capita monthly income is less than $\mathrm{R} \$ 70$ (or U\$29.8). The World Bank considers those who survive with less than one dollar per day as indigents.

15 K. Lindert, Brazil: Bolsa Família Program..., op.cit., p. 68.

16 The exchange rate of 23.10.2017, R\$ $1=$ EUR 0.27. This exchange rate will be used in the subsequent analysis.

17 T.J. Eger, et.al., Money and Morality in the Bolsa Família, "Vibrant: Virtual Brazilian Anthropology" 2014, 11(1), p. 255.

18 Lindert et al., The Nuts and Bolts..., op.cit., p. 51.

19 Eger et.al., Money and Morality..., op.cit., p. 255.

20 Lindert, Brazil: Bolsa Família Program..., op.cit., p. 68. 
Table 1: Monthly grants from BF in 2014

\begin{tabular}{|l|l|l|l|l|l|}
\hline Level of poverty & $\begin{array}{l}\text { Monthly per } \\
\text { capita Family } \\
\text { Income }\end{array}$ & Basic Grant & $\begin{array}{l}\text { Grant per } \\
\text { Children Aged } \\
0-15 \quad \text { (max. 3 }\end{array}$ & $\begin{array}{l}\text { Grant per } \\
\text { Children Aged } \\
\text { Children) } \\
\text { Children) }\end{array}$ \\
\hline Moderately poor & $\mathrm{R} \$ 71-\mathrm{R} \$ 140$ & $\mathrm{R} \$ 0$ & $\mathrm{R} \$ 32$ & $\mathrm{R} \$ 38$ \\
\hline Extremely poor & Up to R\$ 70 & $\mathrm{R} \$ 70$ & $\mathrm{R} \$ 32$ & $\mathrm{R} \$ 38$ \\
\hline
\end{tabular}

Source: the author's own elaboration.

Thirdly, BF's cash transfers are attached to the condition that all age-relevant family members have to comply with key human development. The conditionalities are of high importance, on the one hand, for beneficiaries themselves as a means to overcome intergenerational transmission of poverty; and on the other hand, under the premise that society owes them the debt of past exclusion, conditionalities reassure taxpayers no beneficiary receives too much money too easily. Gradual consequences for non-compliance with conditionalities are implemented starting from a warning, then blockage, followed by suspension and ultimately benefits are cancelled. The philosophy behind the gradual punishment is that the first signal ('red flag') should be interpreted by the local and federal authorities as a family being at risk or needing additional service, with the implication of additional care ${ }^{21}$. A substantial degree of legitimacy exists due to the fact that beneficiaries are co-responsible for the transfer in the form of these human capital conditionalities ${ }^{22}$.

Two kinds of conditionality exist: health and educational. (1) The BF's health conditionalities include complete vaccinations according to the recommended schedule, regular health check-ups, monitoring of growth for children aged 0-7, pre- and post-natal check-ups for pregnant women, participation in health and nutrition related seminars carried out in municipalities ${ }^{23}$. (2) The educational conditionalities state that families must keep children aged 6-15 years old enrolled in school (up to three children per family), showing a minimal attendance of $85 \%$ and adolescents aged 16 and 17 years old ${ }^{24}$ (up to two children per family) need to attend school at least $75 \%$

\footnotetext{
21 Kerstenetzky, Redistribution and Development?... op.cit., p. 16.

22 Lindert et.al., The Nuts and Bolts..., op.cit., p. 55.

23 Ibidem, p. 59.

24 Since 2009, there has also been a grant for children aged 16-17 if they attend high school. Prior to that, only children up to the age of 15 were taken into consideration.
} 
of the school year ${ }^{25}$. The monetary aid in regard with the conditionality on education is essential due to the fact that parents need to overcome economic and social barriers in order to enrol children in schools. Such barriers are, for example, direct costs like school fees, uniforms and books and also the opportunity cost of the time in school as children spend none to less time working or doing other activities ${ }^{26}$.

Table 2: Menu of BF conditionalities

\begin{tabular}{|c|c|c|}
\hline & Health Conditionalities & Education Conditionalities \\
\hline Children & $\begin{array}{l}\text { For all children aged 0-7: } \\
\text { - Vaccine schedule } \\
\text { - Regular health check-ups } \\
\text { - Regular growth monitoring }\end{array}$ & $\begin{array}{l}\text { - Guarantee at least } 85 \% \text { minimum daily school } \\
\text { attendance each month for school-aged } \\
\text { children between } 6-15 \\
\text { - Guarantee at least } 75 \% \text { minimum daily school } \\
\text { attendance each month for adolescents aged } \\
16 \text { and } 17\end{array}$ \\
\hline $\begin{array}{l}\text { Women (pregnant } \\
\text { or lactating) }\end{array}$ & $\begin{array}{l}\text { - Pre-natal check-ups } \\
\text { - Post-natal check-ups } \\
\text { - Participate in educational health and nutrition } \\
\text { seminars offered by local health teams }\end{array}$ & $\begin{array}{l}\text { Parents: } \\
\text { - If a child misses school, school must be } \\
\text { informed of the reason } \\
\text { - Inform the local BF coordinator if a child } \\
\text { moves schools }\end{array}$ \\
\hline
\end{tabular}

Source: the author's own elaboration.

\section{Evaluation of Bolsa Família's Impact}

The impact and limitations of BF which are partly rooted in Brazil's history as well as in its economic, political and social developments will be evaluated. Although the areas of the impact cannot be analysed separately due to its interconnected nature and spill-over effects, the impact is clustered as following: inequality, poverty and economy, education and health as well as women. Moreover, it will be tested on how many SDG Goals BF broaches and how they are influenced by the programme.

\subsection{Impact on Inequality, Poverty and the Economy}

Despite significant decreases in inequality and poverty, Brazil remains to be one of the most unequal countries in the world. One reason for the improvement is the extensive impact BF has had on inequality and poverty in correlation with BF's chief

25 Eger et al., Money and Morality..., op.cit., p. 255.

26 P. Kassouf et al., The Impact of the Bolsa Escola/Familia Conditional Cash Transfer Program on Enrollment, Drop Out Rates and Grade Promotion in Brazil, "Journal of Development Economics" 97(2), p. 505. 
objectives, although a direct causality is difficult to draw. A similar importance is given to poverty and inequality reduction as well as to establishing a thriving and stable economy by the UN in terms of SDG Goals: three out of 17 SDG Goals focus on inequality and poverty reduction, namely (Goal 1) to end poverty in all forms, (Goal 2) to end hunger, (Goal 8) to establish inclusive and sustainable economic growth and (Goal 10) to reduce inequality among states.

First of all, after the implementation of BF, the income distribution improved significantly between 2002 and 2007 as well as the Gini coefficient decreased from 0.593 to 0.542 , which represents an annual average reduction of $1.12 \%$. Secondly, the reduction in poverty is noteworthy. From 1990 to 2009 the proportion of people living in poverty decreased in Brazil by $44 \%$, while the greatest reduction occurred after the introduction of $\mathrm{BF}$ and the economic growth accelerated ${ }^{27}$. According to The Guardian, mentioning a study by the Brazilian Research Institute for Applied Economics, $\mathrm{BF}$ is responsible for approximately $28 \%$ of the total poverty reduction. Francisco Menezes, who works for the Brazilian Institute for social and Economic Analyses, goes one step further saying that hunger is undeniably non-existent in Brazil anymore ${ }^{28}$. Thirdly, the national and local economy has profited from BF, although it is unclear what impact BF has had. Formal employment rates have constantly risen since the implementation of BF. A possible explanation is that due to an increase in consumption on account of the monetary transfer to BF beneficiaries an intensified circular economy is established: more consumption leads to more sales and more production, which, eventually, leads to a creation of additional job opportunities in different sectors. Moreover, a contribution to economic growth is ascribed to the growth of the non-retail sector such as automobile and construction industries, as well as more credit access and employment of BF-beneficiaries and non-beneficiaries. Hence, as the Keynesian economics indicates, the multiplier effect and spill-overs will benefit the population that is not receiving BF as well. However, in order for a beneficiary to become an inclusive part of the labour force and in order to escape in the long-term the structural poverty trap, beneficiaries should invest in training to hold diplomas and skillsets in order to become employees and entrepreneurs of the future formal economy ${ }^{29}$.

\footnotetext{
27 D. Sánchez-Ancochea et al., Bolsa Família, Poverty and Inequality: Political and Economic Effects in the Short and Long Run, "Global Social Policy" 2011, 11 (2-3), p. 305.

28 C.N. Janeiro, Bolsa-Família: Template for Poverty Reduction or Recipe for Dependency? "The Guardian" 2013, http://www.theguardian.com/global-development-professionals-network/2013/nov/05/bolsa-familia-brazil-cash-transfer-system (retrieved: 11.06.2016).

29 B.S. Barreto Souza, Bolsa Família: A Way out of Poverty or a Welfare Trap? A 2030 Backcasting of the Brazilian Conditional Cash Transfer Program, "Asian Journal of Public Affairs" 2013, 6(1), p. 117.
} 
The overall situation in Brazil in terms of poverty is characterized by immense regional differences. Pereira mentions studies by Rocha 2008, demonstrating that BF's impact on the reduction of poverty depends highly on the location of the poor. The relative effect of the transfer is significantly smaller on the urban poor than in rural areas $^{30}$. Hence, BF has had a larger impact on poverty reduction in rural areas, particularly in the north-east. Nevertheless, exclusion also exists with BF and since many were excluded in the past from receiving social benefits, including indigenous communities and street dwellers, the topic needs to be mentioned. There are several possibilities of exclusion from the programme: by design (children either older than 17 or not attending school), by choice (self-exclusion) or by error (family not identified as poor by social workers ${ }^{31}$. However, BF has small leakage compared to other CCTs worldwide. The programme's design is characterized by targeting accuracy in terms of minimizing leakages ${ }^{32}$. To a similar conclusion comes the Food and Agriculture Organization (FAO), stating that BF is the best targeted CCT scheme in Latin America where $73 \%$ of benefits reach the poorest $20 \%$ of the population, while $94 \%$ fall within the lowest two quintiles ${ }^{33}$.

Brazil as an ample country faces difficulties with regional disparities that are immanent also with $\mathrm{BF}$ as the programme with its one-size-fits-all structure creates distinct geographic impacts. On the one hand, there is an urban and rural divide and on the other hand, a regional division between the north-east and the south-east counterparts $^{34}$. The Economist summarized that BF works less well in cities for two reasons. Firstly, the same amount of benefits is given to beneficiaries nation-wide; however, differences such as in housing expenses are not being taken into consideration. Secondly, in cities child labour was not efficiently combated as in rural areas since earnings in cities are greater than the benefits from BF. In rural areas child labour is temporary, for example during harvest; therefore, it is still in accordance with the $15 \%$ rule by the school attendance conditionality. Thirdly, BF affects the household structure in favelas as the benefit goes usually to the mothers as the heads of households. Due to expensive housing in favelas, young women who already have a child of their own, stay with their mothers (the new child's grandmother). Hence, a double dependency is created on the family grant and on the matriarch ${ }^{35}$.

30 Pereira, Bolsa Família and Democracy..., op.cit., p. 1691.

31 S. Higgins, The Impact of Bolsa Familia on Poverty: Does Brazil's Conditional Cash Transfer Program Have a Rural Bias?, "The Journal of Politics and Society" 2012, 23(1), p. 107.

32 Lindert et al., op.cit., p. 117.

33 S. Handa et al., The Experience of Conditional Cash Transfers in Latin America and the Caribbean, ESA Working Paper No. 06-07, FAO, 2006, http://www.fao.org/3/a-ag429t.pdf (retrieved: 10.11.2017).

34 Sánchez-Ancochea et al., Bolsa Família, Poverty and Inequality..., op.cit., p. 307.

35 The Economist, How to Get Children out of Jobs and into School, "The Economist" 2010, http://www. economist.com/node/16690887 (retrieved: 26.05.2016). 
In conclusion, it is arguable to which exact extent BF has had an impact on reducing Brazil's income inequality; however, it is clear that it has had an impact. Similarly, the reduction in poverty can be attributed to the programme. Hence, a legislative alteration of BF should be aimed at, in order to include the poor based on the living standard and the affordability of a basic food basket. Moreover, due to the income volatility of near-poor families are at danger to become poor; therefore, a broader system of safety nets is needed. However, the main problem is the informal sector which is neither regulated nor measured. This unbalances the economy and leads to anomalies and disparities. Hence, SDG Goal 1, 2, 8 and 10 are influenced positively by BF.

\subsection{Impact on Education and Health}

Most economists concede that increased levels of education can lead to economic growth, higher incomes and a higher quality of life ${ }^{36}$. The UN is also highly concerned with the education and health, which is apparent in its SDG Goal 2, 3 and 12 , to be precise, the focus is given to improved nutrition, to ensure healthy lives as well as promote wellbeing and to ensure sustainable consumption, respectively. This subchapter will assess the impact on education, impact on health and finally the quality of the public services.

The enrolment of school-aged children is a conditionality in the BF programme. In general, it can be said that BF has increased girls' school participation by $8.2 \%$; however, no impact can be found on boys' participation. Similarly, grade progression was influenced by BF as girls living in rural and urban areas increased. Boys, on the other hand, only improved statistically in grade progression, grade repetition and dropout but only for young men aged 15-17 in urban areas. Hence, girls are impacted by BF positively; however, this cannot be driven by direct incentives as $\mathrm{BF}$ does not distinguish between sexes. A possible explanation is that girls spend less time on domestic work, which allows them, in turn, to concentrate on studying, creating the beneficial effect on girls' grade progression. Despite the positive result for girls, BF appears to be affecting the gender gap, widening it in favour of girls. Although policies favouring girls' education may be constructive for various reasons, but only when a gender gap already exists. In this case an opposite gender gap is widening; hence, a different approach to neutral policies has to be examined if this would promote boys' education ${ }^{37}$.

36 Kassouf et al., The Impact of the Bolsa..., op.cit., p. 505.

37 de Brauw et al., The Impact of Bolsa Família on Schooling..., op.cit., p. 313. 
BF's health conditionalities require women and their children to receive medical check-ups, vaccinations and growth monitoring. First of all, an increased utilization of preventive health care service has been assessed. Hence, the conditionality is effective in terms of check-ups. However, only a small impact on health care utilization in cases of illnesses and emergencies has been noted. Perhaps, beneficiaries need more time in order to adapt and to trust health care facilities. However, it is apparent that BF is less effective in improving outcomes such as diarrhoea or physical functioning which would require interventions in the form of an improved sanitation and improved living environment. Secondly, BF's greatest impact is on child mortality, which is mainly attributed to poverty-related causes of death and which can be prevented by primary care service. However, it is unclear if the drop in infant and child mortality is primarily due to the poverty reduction with the help of cash payments, or as a result of increased utilization of the health care service, which stems from the health conditionality; a possible explanation is also a combination of $\mathrm{BF}$ components ${ }^{38}$. Thirdly, BF has created positive spill-over effects to older siblings who are 7 to 17 years old and no longer obliged by the programme's design to comply with the health conditionality. Lastly, infant malnutrition has been affected significantly by $\mathrm{BF}$ as well, with a particularly positive effect on children between six and 11 months of age. BF's impact on other age groups was also positive, however, smaller for children aged one to three years old ${ }^{39}$.

The effectiveness of the two conditionalities depend highly on the quality of the service provided as well as on its availability. Since the Constitution of 1988 , the system has undergone a deep restructuring, including a universal access to public services and a pragmatic decentralization approach ${ }^{40}$. Hence, a trend of increased expenditures and efforts to reach all citizens is experienced, while not providing the corresponding levels of quality ${ }^{41}$. The health system in Brazil remains highly segmented, providing poor services, in particular in regions where $\mathrm{BF}$ is most popular. Numbers are alarming, for example, in 2004 public health spending per capita was in the southeast $42 \%$ higher than in the north-east ${ }^{42}$. Besides, considering the high income inequality among Brazilians and the fact that families themselves need to cover around half the expenditures on health, it becomes apparent that health provisions reinforce

38 A. Shei et al., The Impact of Brazil's Bolsa Família Conditional Cash Transfer Program on Children's Health Care Utilization and Health, "Getting Started with the Sustainable Development Goals: A Guide for Stakeholders", Sustainable Development Solutions Network, 2014, pp. 5-7.

39 Sánchez-Ancochea et al., Bolsa Família, Poverty and Inequality..., op.cit., p. 308.

40 Kerstenetzky, Redistribution and Development?... op.cit., p. 309.

41 Sánchez-Ancochea et al., Bolsa Família, Poverty and Inequality..., op.cit., p. 309.

42 W. Hunter et al., Transforming Subjects into Citizens: Insights from Brazil's Bolsa Família, "Perspectives on Politics" 2014, 12(4), p. 839. 
social inequality instead of compensating for them ${ }^{43}$. Thus, the system needs further investments in order to attend the existing demand for health care and also to cope with the additional demand which was created due to BF's conditionality.

A similar quality loss occurs in the Brazilian educational system. According to the Programme for International Student Assessment (PISA), which assesses 65 countries in the realm of education, Brazil has ranked at the bottom in all categories, despite some improvements over the years ${ }^{44}$. Hence, due to BF's conditionality, a mere attendance of school does not produce automatically better-educated adults with jobs. Besides, it needs to be borne in mind that it is the first generation of the majority of the Brazilians who have access to regular basic schooling ${ }^{45}$. Therefore, considering Brazil's reality, it is a step forward; however, it needs to be made clear that a mere cash transfer does not function alone. Improvements in education need to be implemented in order to tackle the generational poverty cycle. Moreover, the public schooling system faces multiple problems that need to be addressed, such as in infrastructure, in training and forming teachers that are paid low wages ${ }^{46}$.

In conclusion, the impact on the learning and health outcomes are not as positive as desired. However, Brazil has made impressive steps since 1988 as it implemented a universal right to access to public services as well as expanding these services to the remotest areas of Brazil. Many citizens who were previously excluded, have received these services for the first time ${ }^{47}$. Therefore, considering Brazil's circumstances, the overall situation of Brazilians has improved drastically. Nevertheless, the apparent lack of quality in these services is intolerable. High-quality services could lead in the long-term to higher wages at the bottom of the income distribution, a more educated labour force and a lasting reduction of inequality and poverty. Many Brazilians became increasingly upset with the 'terrible public services' that resulted in a series of demonstrations before the world cup in Brazil in 2013 $3^{48}$. Although the impact was rather small, SDG Goal 2, 3 and 12 have been influenced by BF and have resulted in a higher impact with an increased quality of services provided and incentives given to municipalities as well as doctors and teachers.

43 Kerstenetzky, Redistribution and Development?..., op.cit., p. 14.

44 OECD, Brazil: Student performance (PISA 2015), 2015, http://gpseducation.oecd.org/CountryProfile? primaryCountry=BRA\&treshold $=10 \&$ topic $=$ PI (retrieved: 10.11.2017).

45 F.F. Pires, Child as Family Sponsor: An Unforeseen Effect of Programa Bolsa Familia in Northeastern Brazil, "Childhood" 2014, 21(1), p. 114.

46 Kerstenetzky, Redistribution and Development?..., op.cit., p. 16.

47 Lindert et al., The Nuts and Bolts..., op.cit., p. 9.

48 BBC News, Brazil World Cup: Clashes at Sao Paulo and Rio Protests, BBC 2014, http://www.bbc.com/ news/world-latin-america-27811657 (retrieved: 07.07.2016). 


\subsection{Impact on Women}

As BF's beneficiaries are mainly women, its impact on women and on empowerment needs to be, therefore, assessed in particular. Due to the fact that approximately $50 \%$ of countries' population are women, to empower them and integrate into the labour force, meanwhile enjoying education and enabling them access to financial institutions, results in faster economic growth (UN Women). The achievement of gender equality and female empowerment is a main concern of the UN and hence, represented by SDG Goal 5 .

BF has impacted evidently the decision-making power of women; particularly it allowed Brazilian women to have exclusive control over the usage of birth control as well as over purchases of durable goods. Interestingly, as BF provides transfers per child, it may have induced an increase in fertility as an anticipation of receiving higher payments ${ }^{49}$. Therefore, in the light of this result, it is noteworthy that the decline in fertility has been greater among beneficiaries than other groups ${ }^{50}$.

Another essential impact for women is the financial inclusion and independence. The magnetic benefit card with which BF's transfer is withdrawn is suitable for other basic banking functions, such as access to credit and insurance services ${ }^{51}$. Similarly, female beneficiaries state in a study done in a rural community in the northeast of Brazil that they are relieved to no longer be in debt with local shopkeepers. A feeling of heightened community status was reported due to the newfound ability to pay at the time of purchase ${ }^{52}$. These are small but vital steps towards the financial inclusion of poor women.

However, de Brauw et al. found an increase in women's labour supply in urban areas; whereas a decrease in rural areas occurred ${ }^{53}$. A possible explanation of the different findings is the location of beneficiaries as in rural areas this is due to greater remoteness and longer travel to work as well as to clinics and school in order to comply with conditionalities. Moreover, the correlation of the decreased female labour supply and impact on children might be desirable and an intended or unintended outcome of the programme, as the reduction in working hours can benefit early

\footnotetext{
49 A. de Brauw et al., The Impact of Bolsa Família on Women's Decision-Making Power, "World Development" 59, 2014, p. 487.

50 Pereira, Bolsa Família and Democracy..., op.cit., pp. 1690-1691.

51 Higgins, The Impact of Bolsa Família..., op.cit., p. 103.

52 Hunter et al., Transforming Subjects into Citizens..., op.cit., p. 843.

53 de Brauw, The Impact of Bolsa Família..., op.cit., p. 496.
} 
childhood developments ${ }^{54}$. The early childhood is critical in terms of nourishment and education, which can prevent future social exclusion ${ }^{55}$.

Hence, it can be argued that BF implies a retraditionalisation of the mother as the caretaker concept. Mothers are responsible for receiving the transfer which was intentional by policy-makers as women allegedly are more capable of taking decisions benefitting the family as a whole. Hence, women gained control of the money and, to some extent, autonomy, which can be regarded as a new form of power. The impact of BF on women is a two-fold process: on the one hand, a retraditionalisation of gender roles occurs, in which a focus is placed on the traditional role as women, the caretakers of children, elderly and households; reinforcing the idea of traditional families and their values ${ }^{56}$. The underlying assumption is that women are self-sacrificingly devoted to the role of motherhood. Hence, women are trapped in the domestic area, perhaps even restricted by the programme to move from the private to the public sphere as necessary. On the other hand, a process of feminine liberation has occurred, due to the empowerment of women who no longer are financially dependent on their husbands, having money of their own and being able to spend it as they desire ${ }^{57}$.

To sum up, BF has impacted women positively in the spheres of decision-making power and financial independence. BF has modified wife-husband and fatherchildren relationships, putting an emphasis on the traditional female role as mother. In terms of the impact on SDG Goal 5, BF has influenced women's empowerment positively and contributed to gender equality in financial terms. Nevertheless, gender inequalities cannot be addressed without structural change to alleviate poverty in general and create a more equal society.

As a general conclusion, it can be summarized that the BF programme has had a significant effect on the quality of life of beneficiaries, as they reported to feel their heightened status due to the financial independence, application for identity documents and enhanced decision-making power. The impact of BF on the inequality and poverty as well as the labour market is not as convincing as it was desired; however, the overall situation has improved in the mentioned areas, mainly due to enhanced economic output and work income. Particularly, the improvement in the quality of public services provided in education and health needs to be a priority. Due to BF being originally a poverty reduction policy, its effects have spilled to other areas. Moreover, BF has influenced eight out of 17 SDG Goals. Thus, BF is a social policy

54 Higgins, The Impact of Bolsa Família..., op.cit., p. 102.

55 Kerstenetzky, Redistribution and Development?..., op.cit., p. 19.

56 Pires, Child as Family Sponsor..., op.cit., p. 139.

57 Eger et al., Money and Morality..., op.cit., p. 276. 
with broad possibilities of application. However, BF needs to be part of a broader, coherent Brazilian policy approach in order to contribute genuinely to sustainable development in all spheres. With adjustments to the policy and lessons learnt from the Brazilian case, BF could serve as a model for other countries as it is a relatively lowcost policy, impacting a wide range of problematic areas in sustainable development.

\section{Conclusion and Recommendations}

To combat poverty is a priority in sustainable development policies; however, as the findings of BF's impacts demonstrate, it is highly difficult for policy-makers to create a policy that successfully addresses the wide range of problems in which the effect is poverty. Nevertheless, BF has contributed with its programme to sustainably developing further its country, in particular to decreasing poverty and inequalities. Therefore, it needs to be seen as a positive example, also because beneficial spill-over effects to other unintended areas have been experienced, which sustainable development also tries to address, such as gender equality and inclusion (as it can be seen in figure 1). The contribution of BF to creating a vibrant democracy and a more engaged citizenry will have a long-lasting effect on the political, social and economic life of Brazil. Also, BF's special focus on women and children and its search for equality will have positive effects on future generations. BF is an appropriate policy to alleviate poverty and other factors of poverty and to provide its expertise to other countries in the Global South in order to meet SDG goals in 2030.

However, corruption scandals, the failure to improve state services and people's unmet demand for a redistribution not only in income but also in land, has increased mistrust and discontent in the population. This was seen already in 2013 and, since 2015 , new waves of protest have emerged ${ }^{58}$.

In conclusion, it is clear that $\mathrm{BF}$ has positively contributed to various sectors of the Brazilian poor people's lives; however, the government has failed to take actions to guarantee adequate state services, such as schools and hospitals. Moreover, as measures to combat Brazil's eroded infrastructure and labour market were given priority, other policy fields were disregarded, which eventually would have led to the creation of an economically prosperous, socially-concerned, and environmentally-friendly Brazil. The first step has been taken as new consumers of public goods,

58 S. Pearson, Brazilians Take to the Streets in Anti-Government Protests, Financial Times 2016, http:// www.ft.com/cms/s/0/937b777e-e934-11e5-9fca-fb0f946fd1f0.html\#axzz4EZoiDqSw (retrieved: 16.07.2016). 
who are becoming politically active, have appeared, which will affect future (presidential) elections and influence political agendas. Another main problem lies with globalisation and the unbalanced market economy, which give rise to disproportionate advantages to a selected few who are globally connected and can take advantage of benefits which are outside the reach of the majority, such as oligopolies and monopolies of power and wealth. BF constitutes a good start, but it needs to be part of a wider restructuring process which would include a transition of the economy and society into being more equal and more efficient in resolving problems through increased democracy and participation.

Figure 1: Effects of BF

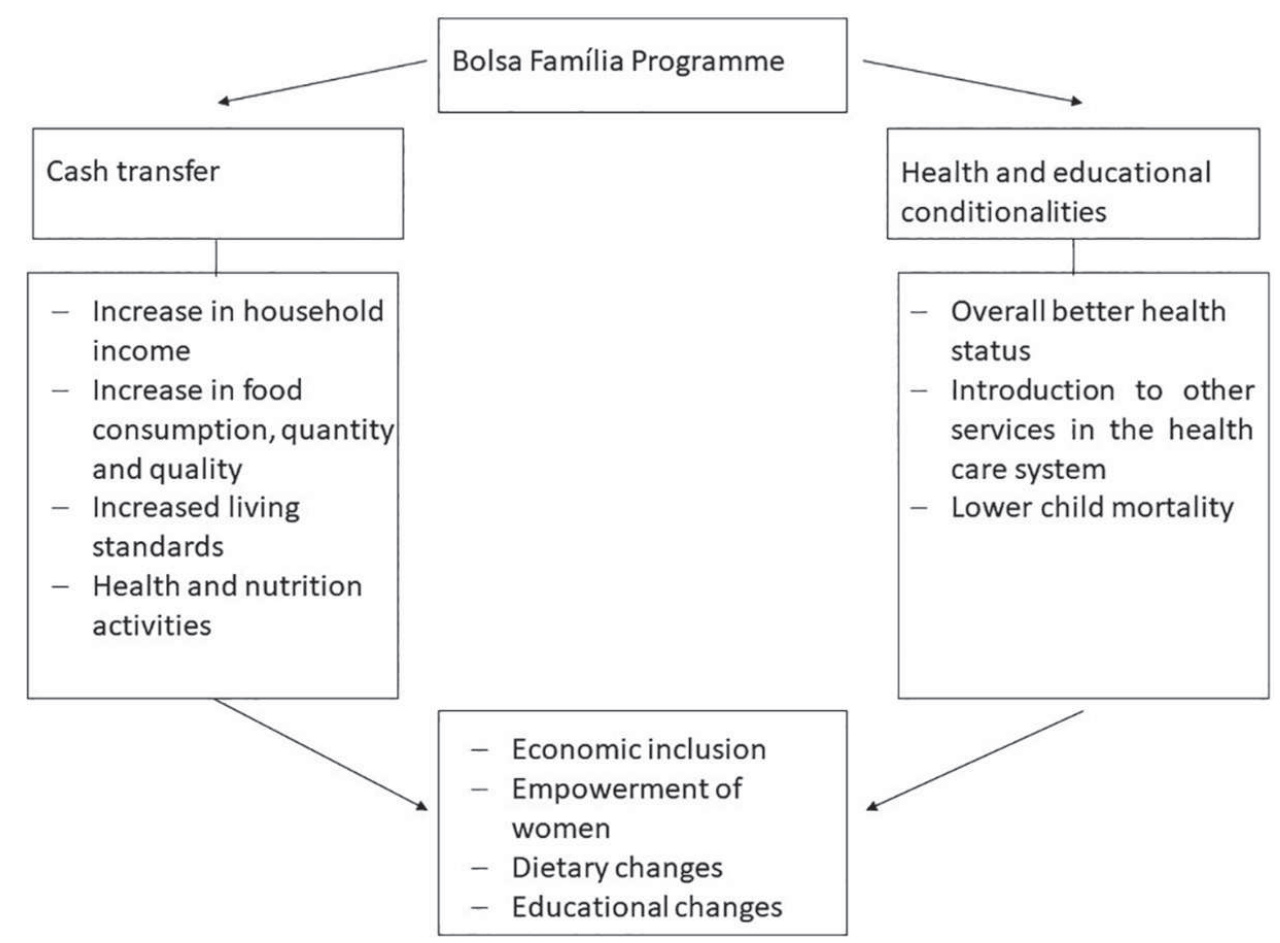

Source: the author's own elaboration.

\section{Recommendations}

Problems that Brazil is facing are concerns of other countries as well, particularly of MICs. Thus, BF could be one tested and comprehensive policy framework that contributes meaningfully to a more egalitarian national as well as global system. Beside poverty and inequality, numerous other obstacles exist that occupy politics and society: unemployment, ageing, jobless growth, et cetera. In these areas Brazil can learn from others that have implemented relatively successful policies to address the mentioned problematic areas on a reciprocity basis. With adjustments to the 
existing policy to meet national demands and wishes, certain areas of policies can be successfully transferred.

Global know-how has to be distributed in order to tackle the most pressing social, economic and environmental challenges. As empirically-tested expertise and experience exists, knowledge sharing has to encounter new mechanisms to tap them globally to promote mutual learning and discuss them in the process of domestic reform for a common aim of sustainable development, for example, through global networks and sharing platforms. Through a possible linkage to the mechanisms, national reform initiatives, too, are more likely to be successful and ensure a demonstrable and sustainable impact for the 'new bottom billion'.

\section{Bibliography}

Barreto Souza, B.S., Bolsa Família: A Way out of Poverty or a Welfare Trap?: A 2030 Backcasting of the Brazilian Conditional Cash Transfer Program, "Asian Journal of Public Affairs" 2013, 6(1), pp. 111-128.

BBC News, Brazil World Cup: Clashes at Sao Paulo and Rio Protests, BBC2014, http://www. bbc.com/news/world-latin-america-27811657 (retrieved: 07.07.2016).

de Brauw, A. et al., The Impact of Bolsa Família on Women's Decision-Making Power, "World Development" 2014, 59, pp. 487-504.

de Brauw, A., et al., The Impact of Bolsa Família on Schooling, "World Development" 2015, 70, pp. 303-316.

Curry, M. et al., Brazil's Bolsa Familia and the Philippines' "4Ps" CCT Programs: Considering South-South Cooperation for Social Protection, "Asia-Pacific Social Science Review" 2013, 13:1, pp. 1-15.

Eger, T.J. et al., Money and Morality in the Bolsa Familia, "Vibrant: Virtual Brazilian Anthropology" 2014, 11(1), pp. 250-284.

Gönner, T., Beyond Development Aid: Novel International Cooperation Approaches with Emerging Economies, Global Economic Symposium, Berlin 2013, p. 3.

Handa, S. et al., The Experience of Conditional Cash Transfers in Latin America and the Caribbean, ESA Working Paper No. 06-07, FAO, 2006, http://www.fao.org/3/a-ag429t. pdf (retrieved: 10.11.2017).

Higgins, S., The Impact of Bolsa Familia on Poverty: Does Brazil's Conditional Cash Transfer Program Have a Rural Bias?, "The Journal of Politics and Society" 2012, 23(1), pp. 88-125.

Hunter, W. et al., Transforming Subjects into Citizens: Insights from Brazil’s Bolsa Família, "Perspectives on Politics" 2014, 12(4), pp. 829-845. 
ILO, Bolsa Familia: An International Example of Social Inclusion. An Interview with Helmut Schwarzer, 2015, http://www.socialsecurityextension.org/gimi/gess/ShowWiki. action?wiki.wikiId=3044 (retrieved: 16.11.2017).

Janeiro, C.N., Bolsa-Família: Template for Poverty Reduction or Recipe for Dependency?, "The Guardian" 2013, http://www.theguardian.com/global-development-professionals-network/2013/nov/05/bolsa-familia-brazil-cash-transfer-system (retrieved: 11.06.2016).

Kassouf, P. et al., The Impact of the Bolsa Escola/Familia Conditional Cash Transfer Program on Enrollment, Drop Out Rates and Grade Promotion in Brazil, "Journal of Development Economics" 97(2), pp. 505-517.

Kerstenetzky, C.L., Redistribution and Development? The Political Economy of the Bolsa Família Program, "Dados" 2010, vol. 10, Rio de Janeiro.

Lindert, K. et al., The Nuts and Bolts of Brazil's Bolsa Família Program: Implementing Conditional Cash Transfers in a Decentralized Context, Social Protection Discussion Paper 709, The World Bank, Washington D.C. 2007.

Lindert, K., Brazil: Bolsa Família Program-scaling-up Cash Transfers for the Poor, "Managing for Development Results Principles in Action: Sourcebook on Emerging Good Practices”, The World Bank, Washington D.C. 2005.

OECD, Brazil: Student performance (PISA 2015), 2015, http://gpseducation.oecd.org/ CountryProfile? primaryCountry=BRA\&treshold $=10 \&$ topic $=P I$ (retrieved: 10.11 .2017 ).

Pearson, S., Brazilians Take to the Streets in Anti-Government Protests, "Financial Times" 2016, http://www.ft.com/cms/s/0/937b777e-e934-11e5-9fca-fb0f946fd1f0.html\#axzz4EZoiDqSw (retrieved: 16.07.2016).

Pereira, A.W., Bolsa Família and Democracy in Brazil, “Third World Quarterly" 2015, 36(9), pp. 1682-1699.

Pires, F.F., Child as Family Sponsor: An Unforeseen Effect of Programa Bolsa Familia in Northeastern Brazil, "Childhood" 2014, 21(1), pp. 134-147.

Sánchez-Ancochea, D. et al., Bolsa Família, Poverty and Inequality: Political and Economic Effects in the Short and Long Run; "Global Social Policy" 2011, 11 (2-3), pp. 299-318.

Shei, A. et al., The Impact of Brazil's Bolsa Família Conditional Cash Transfer Program on Children's Health Care Utilization and Health, "Getting Started with the Sustainable Development Goals: A Guide for Stakeholders", Sustainable Development Solutions Network, 2014, pp. 1-25.

Tepperman, J., Brazil's Antipoverty Breakthrough, "Foreign Affairs" 2016, 95(1), pp. 34-44.

The Economist, How to Get Children out of Jobs and into School, "The Economist" 2010, http://www.economist.com/node/16690887 (retrieved: 26.05.2016).

UN Women (n.d.), Facts and Figures: Economic Empowerment [online] available from http://www.unwomen.org/en/what-we-do/economic-empowerment/facts-and-figures (retrieved: 13 June 2016). 
United Nations, United Nations Secretary-General Ban Ki-Moon, 2013, http://www.un.org/ sg/STATEMENTS/index.asp?nid=7072 (retrieved: 13.10.2017).

WCED, Our common future. Report of the World Commission on Environment and Development, G.H. Brundtland, (Ed.), Oxford 1987.

\section{Combating Poverty as a Main Challenge of Sustainable Development: The Case of Brazil's Bolsa Família}

Brazil's conditional cash transfer Bolsa Família is one of the largest poverty reduction policies worldwide, providing cash transfers to poor households on the condition of fulfilment of a series of health and schooling requirements. Bolsa Família helps 13.8 million families or $25 \%$ of the total population. Since its launch in 2003 results are the following: poverty in Brazil has notably decreased; three million people left poverty and four million are no longer indigent; the Gini coefficient and Human Development Index has improved. Therefore, Brazil has implemented a policy in the realm of sustainable development strategies, combatting the most pressing and degrading condition of deprivation: poverty. As Bolsa Família's impact became prominent due to international media and international organisations, 63 countries have sought Brazilian expertise on social policies. The aim of this essay is to assess if Bolsa Família is an effective mechanism for sustainable development, particularly poverty alleviation.

Keywords: conditional cash transfer, poverty, inequality, SDGs, policy transfer

\section{La prévention de la pauvreté en tant que défi pour la politique du développement durable: le cas de Bolsa Família}

Le transfert conditionnel en espèces "Bolsa Família” opérant au Brésil est l'un des plus grands programmes au monde conçus pour lutter contre la pauvreté. Le programme fournit des ressources financières aux familles qui satisfont à des conditions strictement définies en matière de protection de la santé et d'éducation. Le programme Bolsa Família aide 13,8 millions de familles, soit près de $25 \%$ de la population brésilienne. Depuis son introduction en 2003 les effets suivants ont été observés: la pauvreté au Brésil a considérablement diminué; trois millions de personnes sont sorties de la pauvreté et quatre millions ne vivent plus dans le dénuement; il y a eu une amélioration significative du coefficient de Gini et des 
indicateurs de développement social. Le Brésil a mis en œuvre une politique dans le domaine des stratégies de développement durable, luttant contre l'état le plus humiliant pour l'être humain et le plus urgent à combattre qu'est la pauvreté. Laugmentation sensible de l'importance de Bolsa Família, due à l'intérêt porté au programme par les médias et les organisations internationales, a amené près de 63 pays à s'intéresser aux solutions de la politique sociale brésilienne. L'objectif de ce travail est de répondre à la question de savoir si le programme Bolsa Família est un mécanisme efficace pour le développement durable, en particulier dans le domaine de la lutte contre la pauvreté.

Mots-clés: transferts conditionnels en espèces, pauvreté, inégalités sociales, objectifs du développement durable, politique de transfert

\section{Противодействие бедности как вызов политики устойчивого развития: казус Bolsa Família}

Бразильская программа условных денежных трансфертов «Bolsa Família» является одной из крупнейших в мире программ, направленных на борьбу с бедностью. Программа предоставляет семьям финансовые ресурсы при условии выполнения ими ряда требований к здоровью и обучению. Bolsa Família помогает 13,8 миллионам семей, что составляет около 25\% бразильского населения. С момента ее запуска в 2003 году были достигнуты следующие результаты: бедность в Бразилии заметно уменьшилась; три миллиона человек вышли из бедности, а четыре миллиона больше не нуждаются; коэффициент Джини и Индекс человеческого развития улучшились. Бразилия внедрила политику в рамках стратегий устойчивого развития, борясь с наиболее угнетающим и унизительным состоянием: нищетой. Заметное внимание средств массовой информации и международных организаций, уделяемое программе Bolsa Família, привело к тому, что почти 63 страны заинтересованы опытом Бразилии в области социальной политики. Цель статьи - ответить на вопрос, является ли программа Bolsa Família эффективным механизмом устойчивого развития, в частности в области борьбы с бедностью.

Ключевые слова: условные денежные переводы, бедность, социальное неравенство, цели устойчивого развития, политика в области денежных переводов 